International Journal of Instruction e-ISSN: 1308-1470 • www.e-iji.net

Article submission code: 20200519221726

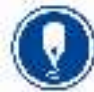

Received: 19/05/2020 Revision: 12/11/2020
April 2021 • Vol.14, No.2

p-ISSN: 1694-609X

pp. 1001-1020

Accepted: 03/12/2020

OnlineFirst: 18/03/2021

\title{
The Affect-Intellect Relationship Mediating Learning and Development of Students in School
}

\section{Eliana de Sousa Alencar Marques}

Prof., Federal University of Piaui - UFPI, Brazil, esalencar123@ufpi.edu.br

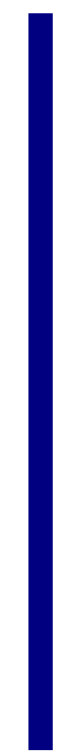

The article discusses results of bibliographic and empirical research with the aim of analyzing the affect-intellect relationship in the process of developing teachers and students who experience successful educational practice. The bibliographical research was based on the ideas of the philosopher Baruch de Espinosa on the nature of affections and their relationship with human development and the production of adequate knowledge, and also on Lev S. Vigotski on perejivânie (experience), a concept that the belarusian developed to explain how human consciousness, in its process of historical development, is mediated by affections. Empirical research used the case study method and involved a high school teacher who teaches mathematics at a public elementary school and four and their former students. The data collection instruments were narrative and memorial interviews. In order to analyze the data produced, the data analysis and validation procedure known as Nuclei of meanings was used. The results show that both the teacher and the four students were positively affected in their school life stories. These positive affects triggered positive affective experiences that impacted the development of the consciousness of teachers and students, a fact that allows the emergence of new psychological functions that guide more powerful human actions, that is, human actions more aware of the need to continue learning and developing, not only at school, but in life.

Keywords: affect-intellect relationship, education, perejivânie (experience), human development, learning

\section{INTRODUCTION}

Based on the assumption that all philosophy remains current while expressing the problems inherent in the era that raised it and is insurmountable as long as the historical moment of which expression has not been overcome (Saviani, 1991), we are among those who consider that Baruch de Espinosa's ideas on the constitution of the human being remain current, since man is the synthesis of multiple determinations and that, among so many determinations, affections continue to figure as the driving force of human actions. In this direction, we consider that the ideas of this philosopher offer valuable contributions to educational research based on some concepts present in his

Citation: Marques, E. S. A.(2021). The Affect-Intellect Relationship Mediating Learning and Development of Students in School. International Journal of Instruction, 14(2), 1001-1020. https://doi.org/10.29333/iji.2021.14257a 
theory of affects. One of these ideas is that in relation to the world, human beings produce adequate rational knowledge of things, mediated by affections.

To deepen this debate, we bring to discussion Lev S. Vigotski, an eminent Belarusian theorist who relies on Spinozian monism to explain that in the development of the human psyche the affect-intellect relationship constitutes a unity, forming perejivânie (experience), a concept that Vigotski develops to explain how human consciousness is constituted in the relationship with the environment, in its process of historical development. The interlocution between the two theorists serves as a basis to confirm the thesis that "the teacher is able to successfully carry out his teaching activity when affects his students for joy, potentiating the students' desire for new learning", to put it another way, success in learning results from the quality of the affect-intellect relationship that mediates the development of students at school. (Marques and Carvalho, 2014, p. 42).

If we take this thesis into account, we can then ask: how does the affect-intellect relationship impact the development of the consciousness of teachers and students to the point of favoring an increase in the desire to continue learning and developing?

As an answer to this problem, we present in this article results of bibliographic and empirical research with the objective of analyzing the relationship between affection and intellect in the process of development of teachers and students who experience successful educational practice.

The meaning of successful educational practice on which we rely is based on the ideas of Vigotski (1996, 2003, 2009), from which we come to the understanding that all good teaching is one that generates learning and collaborates with the development of higher psychic functions, therefore, it is the teaching that contributes for the students to become more human from the socio-historical point of view. From Espinosa's Philosophy (2007), this concept has expanded, so that we come to understand that all educational practices that affect subjects of joy are successful and, consequently, contribute to increase the power of being and acting, both the teacher as well as the student. In other words, successful educational practices are those that, in addition to generating learning and development, enable the expansion of joyful affections that enhance human minds and bodies.

Current research supported by Vigotski, such as that carried out by Paes (2020), Modé Magalhães and Martins (2020), Gazzoti and Souza (2019) Alencar Marques and Carvalho (2018), help us to understand successful education in a developmental perspective, that is, how one that favors the appearance of something new in the individual, of new typically human characteristics. In accordance with this Vigotskian idea, these researchers consider that successful educational practice is one that produces human development according to the historical needs of the time in which we live, that is, that helps us to develop aspects of our personality that have not yet been developed, such as the affections that drive us to be more, to wish to reach our personal goals.

Modé Magalhães and Martins (2020) argue that all good education is one that excels in learning that promotes transformations in the representations of subjects. These 
transformations result from the fact that between the learning subject and the object conceptual systems interpose, which in this way transform the content of the consciousness of the individual who is experiencing educational processes.

Alencar Marques and Carvalho (2018) also contribute to this debate by stating that successful education is one that activates our joy. According to the researchers, joy activates our mind and leads us to build adequate ideas about what we want. Having adequate ideas about what we want means greater awareness in relation to the phenomena of reality, because joy increases our power to think and act. Also according to the researchers, the increase in power leads to a rational, adequate understanding of reality. At school, we contribute to increasing the power of our students when we motivate adequate, rational, organized thinking. When we recognize their potential, when we emphasize their achievements and value their successes.

Contextualizing this in the research scenario, what interests us is to know the potential of educational practices that affect subjects of joy and that, theoretically, are considered successful because they contribute to increase the power of being and acting, both for the teacher and the student. In other words, successful educational practices are those that, in addition to generating learning and development, enable the expansion of joyful affections that value the human mind and bodies. Knowing deeply how these practices are carried out at school can favor the expansion of school success for both teachers and students, hence the relevance of studies of this nature.

The text is organized into three sections. In the first, we analyze the converging ideas between Espinosa and Vigotski in the explanation of what comes to be perejivânie (experience) and its relationship with the affects that mediate the development of conscious activities, and in what sense this concept collaborates in the understanding of the development of successful educational practices at school. In the next section, we bring brief information about the empirical research that supports the discussions in this article. In the third section, we analyze part of the results of empirical research carried out with the aim of analyzing the process of constituting teachers and students who experience educational practices considered successful at school. We conclude with considerations that point out the limits and possibilities that objective reality imposes on human beings in the constitution of themselves as more powerful, therefore, more developed subjectivities.

School educational practices, Perejivânie (experience) and the affect-intellect relationship: reflections from Baruch de Espinosa and Lev. S. Vigotski

The considerations presented here are based on the results of a doctoral research carried out with the objective of investigating the constitutive mediations of teachers and students who successfully experience educational practices at school. However, before we deepen the debate, it is necessary to clarify the following question: what are successful educational practices and how can they be mediated by perejivânie (experience)?

For us, successful educational practice is one that generates learning and collaborates with the development of higher psychic functions, that is, it collaborates with the 
development of thought, language, memory, directed attention, concept formation, awareness, creativity, among many others functions that, according to Vigotiski (2009, 2003,1996), make us qualitatively different from other animals. Expanding this understanding even further, it means that successful is all educational practice that affects the subjects of joy and, consequently, contributes to increase the power of thinking and acting, both for the teacher and the student (Espinosa, 2007, 2008).

In a recent research, Gazzotti and Souza (2019) refined this concept and explained that successful educational practice is consolidated when it promotes the learning of operations that require deliberate awareness and control, because the learning of these operations favors the psychological, social and affective development. That is, the research shows that good teaching is one that enables the experience of emotional experiences, the self-regulation of behavior, the expansion of symbolic development and the establishment of affective bonds in educational situations.

Having clarified our understanding of the meaning of these practices, it is now necessary to clarify how, in our view, they are constituted. Based on Espinosa's philosophy (2008, 2007) and Vigotski's ideas $(2009,2003,2004,1996)$ about the human constitution process, we understand that successful educational practices result from the mediation of the social and the relationship between affection-intellect in the constitution of individuals who develop these practices. And how does it happen?

Espinosa (2008) explains the world made up of two elements that, although essentially different, are integrated. On the one hand, what he calls an infinite and perfect Substance that is the cause of itself and that therefore exists in itself and for itself, needing no other to exist. To this substance he called God or Nature, when explaining, "besides God, no other substance can exist or be conceived." (Espinosa, 2008, p. 29). On the other hand, the other existing beings from this substance he called "modes" of this substance, in which human beings are, as well as everything else that exists in the world; "Everything that exists, exists in God, and without God, nothing can exist or be conceived". (Espinosa, 2008, p. 31).

From this explanation it follows that a Substance cannot be produced by anything else, because it will always be the cause of itself, that is, its essence necessarily involves existence, that is, to its nature belongs to exist. Thus, it is understood that the essence of Substance consists of its existence, therefore "the existence of God and his essence are the one and the same thing." (Espinosa, 2008, p. 43).

The same cannot be said of the finite modes of Substance, that is, of singular entities, for example, human beings. Espinosa (2008) states that "the essence of a singular entity is that which, if given, the thing is put and, if withdrawn, the thing is removed, or that without which the thing cannot exist or be conceived, and conversely, that which without the thing can neither exist nor be conceived. "(Espinosa, 2008, p.93).Having said that, the philosopher then states that what constitutes the essence of singular beings is "the effort by which each thing strives to persevere in its being", that is, the power to exist. It means that nothing has in itself something through which it can be destroyed, because its essence consists of self-preservation, that is, the whole effort of being is to 
continue existing because "nothing has in itself something through which it can be destroyed, that is, to withdraw its existence; on the contrary, it is opposed to anything that can withdraw its existence"(Espinosa, 2008, p. 173-174).

Human beings being singular beings, we can assume that the essence of men is their power. It is the effort to continue to exist. In proposition 10 of part III of Ethics, Espinosa differentiates effort in man when it refers only to the mind. In this case, it is about will; when effort refers to both mind and body, it is called appetite. The appetite, therefore, is nothing more than "the very essence of man, whose nature necessarily follows those things that serve for its conservation, and which man is thus determined to accomplish" (Espinosa, 2008, p. 177), in other words, desire. Therefore, we understand on the basis of Espinosa that desire is appetite together with the awareness of it.

Desire (conscious effort) comes to be understood as the essence of being, as the force that drives the being to exist and perseveres in its being, the conscious effort that varies according to the increase or decrease of our vital energy, which Espinosa (2008) also calls it conatus. This energy is increased or decreased depending on the affections of the body and mind, that is, the capacity that the bodies have to affect and be affected.

Regarding the condition of affecting and being affected, Espinosa (2008, p. 163) clarifies that "the human body can be affected in many ways, by which its power to act is increased or decreased, while so many others do not make its power to act neither greater nor less". On the one hand, our power is increased when we are affected by joy, on the other hand, our power is decreased when we are affected by sadness. Affections are, therefore, "affections of the body by which our power to act is increased or decreased, stimulated or restrained, and, at the same time, the ideas of these affections". (Espinosa, 2008, p. 163).

In proposition I of book III of Ethics, Espinosa (2008, p. 165) clarifies the relationship that exists between the power to act and affections when he states that "our mind sometimes acts; others, in fact, suffer. But specifically, as she has adequate ideas, it necessarily acts; as it has inadequate ideas, it necessarily suffers".

The action presupposes the increase in power. This occurs as we have adequate ideas, we are aware of the reasons that guide our actions, when we give meaning to what we do, when we are clear about what affects us. When we have clear ideas about "what we do" and "why we do it".

On the contrary, we act out of inadequate, confused, mutilated ideas, in short, when we are not clear and aware of the reasons that lead us to act, in fact, we suffer. This is what Espinosa refers to when he says that our mind suffers. Espinosa thus unites two historically separate terms, "action and reason, identifying the power to act with the power to understand." (Costa Pinto and Rodrigues, 2013, p. 115), that is, the more we understand things, not because of what this affect immediately produces in our body, but because of what the thing truly is, the more adequate is our understanding of things. Our action is mediated by conscious, more powerful reasons. On the other hand, when we produce ideas having as a source of knowledge only what immediately the thing produces in us, the result of our sensations, ignoring the true cause of what we feel and 
why we act, in short, the more we ignore the reasons for our actions, more inadequate is the knowledge produced, because the source of that knowledge is confused, mutilated, nebulous ideas. The main consequence of this is the decrease in our power to understand, our relationship with the world becomes passive, because we are not using our power to think.

This proposition, a fundamental idea of Espinosa's philosophy, that thinking is always the result of our affective relationship with the world - in the sense that thinking properly means understanding the reasons that are at the origin of our cognitive ideas, that is, thinking properly is the same as understanding the causes that give rise to our thoughts is the idea that will support Vigotski's thesis that, in man, reason and emotion constitute unity and, therefore, all human action is signified, it is the product of their relationship of meaning with the world.

For Espinosa (2008), to truly know means to know for the causes. It means identifying what drives a person to act, that is, his motives, what drives him to act. Like Espinosa, Vigotski $(2009,2004,1996)$ also understands that human action does not happen apart from motives, affections and emotions. In other words, the author considers that every thought is emotional, therefore, in order to understand in depth what people do, we need to know their reasons, or in the words of Espinosa (2008), the precise cause for which something exists. Therefore, for these two authors, it is the reasons, the causes, that ultimately point out the meaning of our actions and, these senses, are closely related to the type of affectation constituted in the social situation experienced.

This leads to the understanding of two issues. First, that our power to act is closely related to our affections; second, that the increase in our potency is linked to an adequate understanding of what causes our affective states. This has decisive influences on the educational processes.

Costa Pinto (2012, p. 80) explains to us that "the power of human action is of the order of the encounter, since it is related to the infinite possibilities of composition between the affects in the active (actions) and passive (passions) encounters, or that is, it relates to our ability to affect and be affected". This means that if, in the meetings we have with other people, we are affected by joy, the power is increased; if, in these meetings, the predominance is of sadness, the power is diminished. Thus, the meetings represent infinite possibilities, they can be "good, happy, active, potentiating, compatible, or bad, sad, passive, ineffective, incompatible." (Costa Pinto, 2012, p. 84).

The educational process consists of meetings; for this reason, it has the potential to affect teachers and students involved in these meetings with joy and sadness. In the classroom, the meeting between teachers and students can be much more complex than imagined, as this meeting can be marked by situations of joy as well as situations of sadness. This occurs based on the dynamism of our affections, which gives us multiple possibilities to understand reality, since the way we are affected by it is infinitely different. It means that these meetings can constitute what Vigotski (1996) calls Perejivânia (experiences) and as such they can trigger happy and sad affects; they can increase and decrease people's power to be, think, feel and act, a fact that occurs, 
according to Espinosa (2008, p.209), because "each one judges or evaluates, according to his affection, what is good or bad, what is better or worse and, finally, what is great or bad."

And what is perejivânie? What is the relationship of perejivânie with affections? What does this have to do with education?

Perejivanie is the concept that Vigotski $(2009,1996)$ developed to explain how the human being is constituted in the relationship with the environment. In our language the word that comes closest to the meaning of this Russian term is experience ${ }^{1}$. For this theorist, consciousness is only formed in the process of interiorization through social relations constituted in activity. This internalization happens through the mediation of meanings (meanings and senses). Meanings and senses mediate our relationship with the world because it has to do with how we understand and feel the world around us.

The analysis that involves the relationship between meaning and sense cannot lose sight of the fact that meaning is what enriches the word, it is what dynamizes its meaning. This is because, according to Vigotski (2009), the word incorporates, from the entire context in which it is interwoven, the intellectual and affective contents. The senses are, therefore, constituted from cognitive, but also affective, processes. It is based on the idea that thought also has an affective and volitional dimension that this author, when studying human consciousness in its materiality, that is, the individual in activity, clarifies that all human activity is signified and that the analysis of signification of activity involves, above all, the analysis of the motivations, interests, expectations and emotions of the subjects who are in activity.

The meanings and the senses also mediate the transformation of certain life experiences of the subjects into experiences as they lead to the production of meanings that alter the way man relates to reality. The experience encompasses both awareness and the affective relationship with the environment and the person with himself, through which, in conscious activity, the understanding of events and the affective relationship with them are available. Finally, Vigotski $(2009,2003$, 1996) clarifies that experiences are sources of affections that guide the relationships of subjects in and with the world. It is what allows us to understand how each person relates to the world and how that world is subjectified, because the experience involves the production of affections and senses.

In this direction, those who wish to carry out successful practices in education should strive to have happy meetings. These activities are planned and carried out in such a way that they lead students to produce personal meanings, mediators of the desire to continue learning and developing. Joy is the expression of the student's increased power and, in the teaching and learning processes, this occurs when the student learns something that makes sense for his life, when he is aware of what he learns and when learning has meaning. The same needs to happen with the teacher, that is, the teacher needs to

\footnotetext{
${ }^{1}$ From now on we will use the term "experience", as it is the best option for translating the Russian term perejivânie into Portuguese.
} 
produce reasons to remain in teaching and thus feel encouraged to act to keep his students involved with educational practices. In short, meetings in the classroom, at school, in teaching and learning situations need to constitute experiences for teachers and students to produce happy affections capable of potentiating bodies and minds.

Currently, we face two major challenges. First, how can we produce joyful affections if the objective reality in which teaching is carried out and produced in Brazil is increasingly precarious? Is being a teacher in our country increasingly constituted in facing the most vexing and humiliating situations?

Another great challenge that Brazilian educators face is to get their students to produce personal meanings to be in the classroom, to be more and better involved with the contents taught, with the proposed activities. It is increasingly urgent for the school to become a space for joyful meetings, which means the production of pleasure in being at school, both for the teacher and for the student. This can all be strengthened in students with an increased desire for new learning, new experiences and the production of new personal meanings related to school, school content and the relationships shared and experienced with teachers.

Understanding school educational practices through the mediation of joyful emotional experiences can be fundamental to face these challenges for several reasons. One of them is the fact that when teachers understand that the experience of happy social situations increases the power of the students' body and thinking, which suggests a break with the dichotomization between affection and intellect in educational processes, since affection and rationality are dimensions of the human that place it in relation to the world of objects and concepts (Carvalho, et al, 2019). Therefore, educational practices capable of enabling the maximum intellectual development of students are those that provide affective states of personal satisfaction.

Regarding the affect-intellect relationship, Alencar Marques and Carvalho (2018) reiterate that joy activates our mind and leads us to build adequate ideas about the objects with which we relate at school. Having adequate ideas about the objects with which we relate means greater awareness in relation to the phenomena of reality, that is, expansion of our understanding and greater capacity to make use of faculties that need to be stimulated to be developed, such as the ability to reflect critically on things or act creatively through problem situations.

This makes it clear that reason and emotion are not dimensions that exist in the human separately, on the contrary, they exist in an interconnected way. The production of knowledge is always mediated by the relations of meaning, by the way things affect us, as stated by Toassa (2019, p. 355) our concepts about external objects, several concepts used "imply complex forms of ethical-political evaluation that make up our emotions in a structural way, showing how our essence is neither standardized nor made of thoughtless and unthinking flesh."

At school, we contribute to increasing the power of our students when we motivate adequate, rational, organized thinking. When we recognize their potential, when we emphasize their achievements and value their successes. When we organize educational 
situations in which students are led to produce more knowledge and to express more their rational and affective potential.

We understand that it is essential for educators to know how to transform school educational practices into sources of affection, in social situations that enhance the emergence of higher psychology functions in students, such as the development of awareness, critical and creative thinking, the ability to make decisions and regulate one's behavior. Making the school a space in which learning necessarily involves the human capacity that students have to desire, to feel and understand the world, people, objects, in short, the totality.

The desire, according to Silva and Gomes (2017) is the construction that is built through encounters throughout the life of each person. What materializes as desire is the result of the synthesis of this individual's encounter with the world. Situating this at school, the desire that students and teachers produce results from the relationships they experience in the encounters between their bodies that, when they compose, expand, generate new ways of acting in the world, new actions in the world and with the world. Therefore, if it is the desire that affects our body and alters our body composition, driving necessary changes to our way of existing, thinking and feeling, the school needs to potentiate this through educational practices that will become a source of desires because this it is the most potent affect for our development.

Espinosa's ideas help us to understand that educational practices are successful when they lead to an increase in the power of teachers and students. However, this reality does not depend on the spontaneity or the absolute will of the individuals, this reality is constituted in relation to the objective reality. Espinosa's (2008) philosophy shows that all social relations are, at the same time, mediated / mediators of affections that can be happy and sad. From this, we understand that the educational processes, when constituted in the set of social relations, produce and are the product of affections. This means that both teachers and students affect and are affected by what they experience in their daily relationships. Educational practices are the order of the meeting that takes place between teachers and students. In this sense, it is necessary to understand which conditions (objective and subjective) need to be produced so that, at school, teachers and students experience joyful meetings, that is, educational practices that lead to an increase in the power of both and, consequently, to an active desire teachers and students. About this, we will discuss below from empirical research data.

\section{METHOD}

The qualitative research carried out in Brazil between the years 2011 and 2014 was divided into the following stages: 


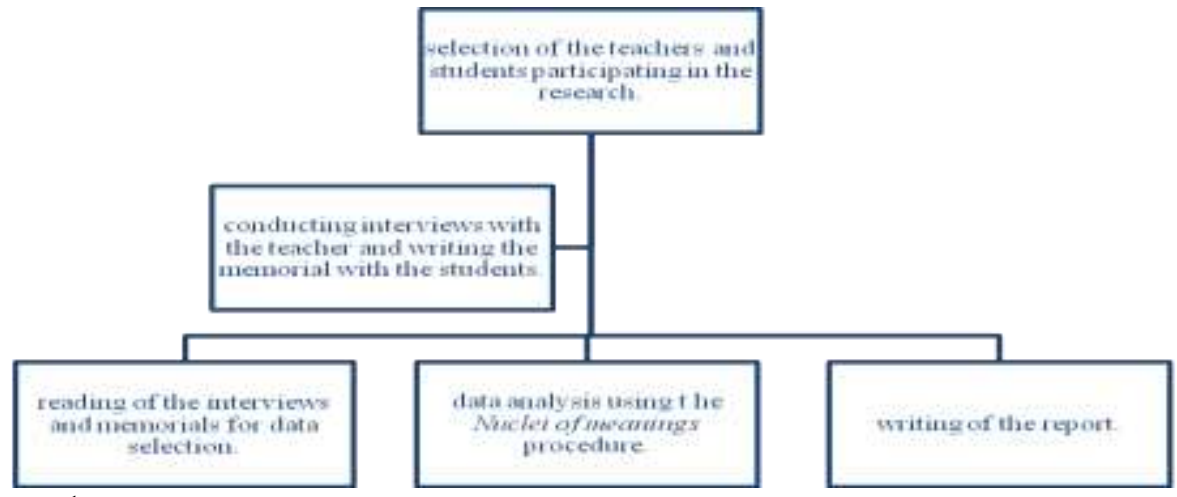

Figure 1

Description of the steps of the empirical research

Source: Data produced in the doctoral research in 2014.

The method adopted in conducting the research was the ase Study. The case study involved a teacher who teaches mathematics in high school at a public school in the northeastern region of Brazil. The research also included the participation of four former students of this teacher. Two male students and two female students. Both the teacher and the four students participating in the research are low-income people living in the countryside in the interior of Piauí, northeastern Brazil, in a city with just over 15 thousand inhabitants. The school where the work was carried out is public and serves low-income students.

For data collection, we conducted three narrative interviews with the teacher. The interviews were recorded and then transcribed. With the students, we wrote the memorial. In order to analyze the data, we used the data analysis and validation procedure known as Nuclei of meanings, which will be further detailed below. The research to which we refer in this article was carried out between the years 2011 and 2014. The subjects were chosen by the criterion of social recognition. In other words, all research participants are recognized (nationally and internationally) as people with successful education stories [2]. We also inform you that all names given to the teacher and students are fictitious. In this article, we present an excerpt of the research carried out with the students.

Based on the idea of Huberman (2007, p. 55) about "the person who knows the most about a given life trajectory is the person who lived it", we chose to work with the students participating in this research, writing the autobiographical memorial. Far from being just a memory, the writing of the memorial is much more of a creation, the result of an attempt to put order in events that had a different order at the time they were lived.

It was exactly for this purpose that we asked the four students to write their autobiographical memorials in order to narrate their family and school life stories, so that we could proceed with the analysis of the social situations narrated that point to situations of affective experiences, especially those related to school life. 
As a procedure for data analysis, we used the proposal developed by Aguiar and Ozella (2013) known as "Nuclei of Meanings". ${ }^{2}$ This analytical procedure, according to Aguiar and Ozella (2013), allows to apprehend the constitutive social mediations of individuals in activity, through meanings expressed in the speeches. In this procedure, we start from the apprehension of the meanings to reach "the most unstable, fluid and deep zones, that is, the zones of meaning" (Aguiar; Ozella, 2013, p. 304). The meanings reveal what is in the appearance, in the discourse, but what interests us is what is in the subtext, what is not shown without a careful and deep analysis, the subject in its essence, what makes it unique.

The analysis of the memorials led us to the identification of three nuclei of meanings. It is important to clarify that each Nucleus of meaning is formed by a set of indicators that expressed, among other things, the reasons, choices, historical paths, experiences, important and decisive relationships for the historical development of these students. In the table below we present the steps that constitute this analysis procedure:

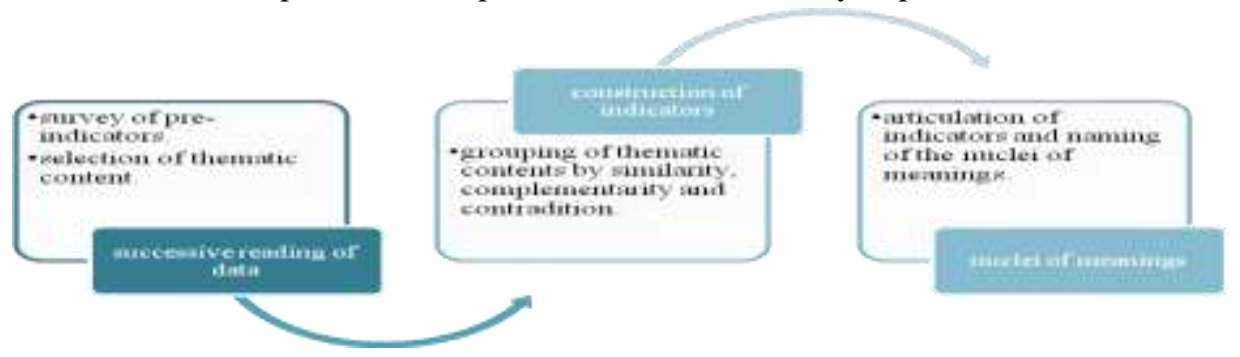

Figure 2

Steps of the data analysis procedure

Source: Data produced in the doctoral research in 2014.

The readings of the four memorials were made in order to achieve two objectives:

1. Analyze meanings and senses produced by students about educational practices;

2. Analyze the affects produced in the experience of educational practices.

In this sense, in the first stage of analysis, we made the first movement: the successive reading of the data. In this initial movement, we tried to select what we call Preindicators and their respective thematic contents in order to find those narrative passages that showed emotions, expectations, way of seeing the school, way of seeing the teacher, difficulties encountered in the course of life as student, facilities, feelings, significant educational practices, moments of joy, sadness, important people. This does not mean that, in the analyzes and interpretations, the other situations reported by the students have been disregarded in any way. All the information produced in the memorials contributed to achieving an understanding that brings us closer to the totality of these subjects.

2 This analysis procedure starts from the word with meaning and basically involves three stages: selection of pre-indicators, survey of indicators and constitution of Nuclei of meanings.

International Journal of Instruction, April 2021 •Vol.14, No.2 
The second movement identified in the Construction of indicators occurs after the analysis of the pre-indicators and the identification of their respective thematic contents. After grouping the pre-indicators and identifying the content that these elements indicate, we assign a name to each grouping. The name should indicate what this grouping reveals of meanings and senses.

The third and last movement of analysis is the constitution of the nuclei of meanings. This step consists of a new grouping, now of indicators. After reading all the indicators and what they reveal in terms of meanings and senses, we put them in another group and renamed them, now, considering only the sense that predominates in each group (Marques, 2014).

The nuclei of meanings that we organize express part of the uniqueness of each student in particular. And, because they are representative of the constitutive mediations of these students in their historical trajectories, these nuclei were named considering these mediations. The table below brings together all the nuclei of meanings with the respective indicators:

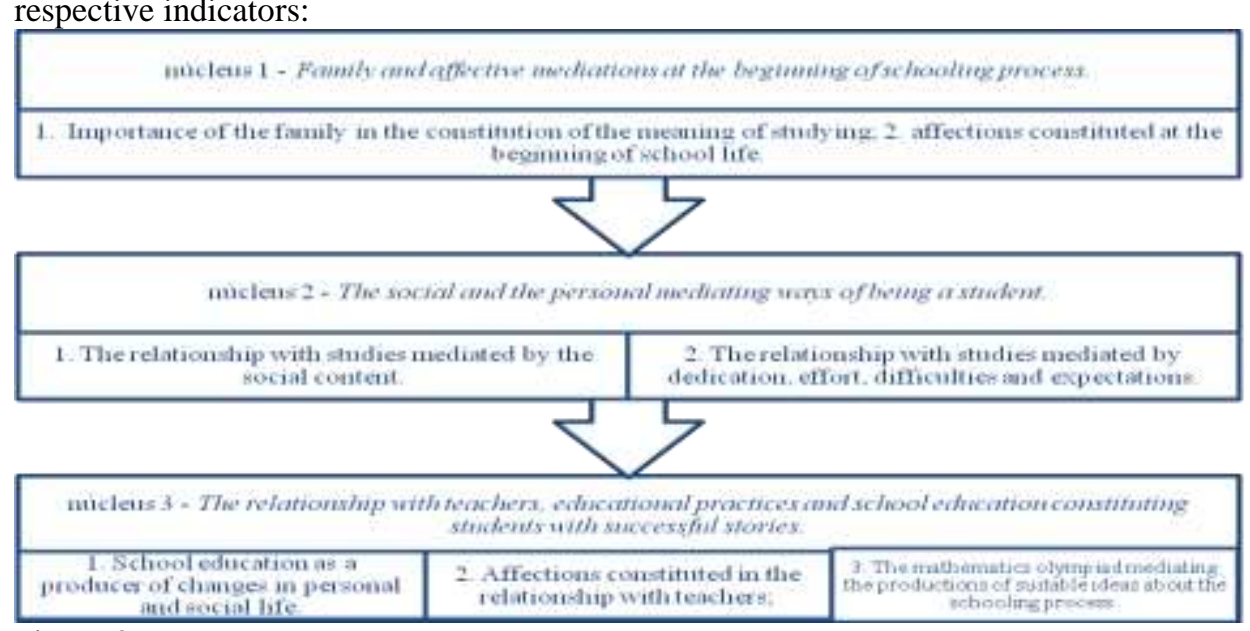

Figure 3

Nuclei of meanings and their respective indicators

Source: Data produced in the doctoral research in 2014.

As illustrated by the figure 3, each nucleus is formed from indicators. In this report, we will analyze the third nucleus of meanings: the relationship with teachers, educational practices and school education constituting students with successful stories. Of the three indicators that make up this nucleus, we will analyze the third indicator: the Mathematics Olympiads mediating the production of suitable ideas about the schooling process. In the analyzes, we articulated discussions in order to demonstrate how this particular educational practice mediated the production of affective experiences that led to the constitution of the students' desire to study in order to learn and develop. 


\section{FINDINGS AND DISCUSSION}

The idea that meanings are transformed in the course of life, and that these transformations indicate that there has been a change in the individual's relationship with the world, we extract from the students' memorials discursive passages that express how the affective relationship with teachers, the peculiarities of certain educational practices and the way each student means school education will mediate the constitution of the meaning of studying to learn and develop. Finally, we will explain how the affectionintellect relationship mediates the constitution of students with a successful school story.

These meanings reflect that, in the historical relationship between students and teachers in the schooling process, some educational practices were constituted in social situations of development because they were producers of experiences. These experiences were sources of affection, sometimes happy, sometimes sad, that guided the production of personal meanings related to studies and school that potentiated the study activity, leading them to experience important transformations for the development of each one, either as a student or as a person.

Affected by the desire to take his students to learn mathematics, Professor Torriceli decided to prepare all his 6th grade students to participate in a different educational practice. This practice refers to participation in the Brazilian Public Schools Mathematics Olympiad (OBMEP), held annually in Brazil, with the purpose of identifying new talents in mathematics. Since 2005, the teacher has organized the preparation of students to participate in all stages of the Olympiad at his school. These steps range from enrolling students to preparing for each phase. To discuss this experience, we selected some excerpts from the memorials written by the students to illustrate how they have meant the involvement with this educational practice:

I remember that Torricelli introduced us to this competition, ${ }^{3}$ but a priori I didn't believe it so much, as I thought it was not possible to get results, even so I met with the other students in the study groups he scheduled, that's where the magic started happening. [...] From then on [the Olympiad], I started having something special to study, no longer to keep school indoctrination alive, but because I felt, and still do, a different feeling when studying mathematics, a mixture of happiness and completeness. (Pythagoras)

The fact that would change my life story and come to become who I am today occurred in the 6th grade, it was during this period that the then math teacher, Professor Torricelli, enrolled all the students of the school for the Brazilian Public Schools Mathematics Olympiad - OBMEP. [...] When I saw it I had been awarded a silver medal, so I wondered, what would that mean? And from then on everything in my life would change [...] I had discovered something that I was good at. (Isaac)

I was very young, I did not understand the value that these Olympiads would have in my life, however, Prof. Torricelli never gave up on encouraging me. [...] I managed to pass

${ }^{3}$ All sections in italics are called pre-indicators. 
that same year to the 2nd phase of the Brazilian Public Schools Mathematics Olympiad [...] I got two Honorable Mentions, and a Bronze Medal. It was in these last three years of study in my city that the influences of my teachers stood out. [...] I loved studying chemistry, biology, mathematics [...] and with the results at the Olympiad, I started to get more and more excited. [...] And all the other teachers realizing the good results that were obtained year after year in schools where prof. Torricelli taught, they started working hard too. $[\ldots]$ GN was the name of my chemistry teacher [...] he started doing the same way as Torricelli, preparing students for the chemistry Olympiad and, as expected, many medals were obtained! [...]. All the other teachers also began to engage in the Olympiad and taught extra classes. (Raquel)

The excerpts from the narratives, although in a different way, express meanings that signal that the students, when participating in the mathematics Olympiad, experienced a transformation in the way they relate to mathematics, studies in other subjects and the school. This indicates that students have changed the relationship with the school context, and what was previously felt in one way, with participation in the Olympiads, has now been felt in another. Thus, we have indications that students experienced situations and relationships at school that triggered the production of powerful affects and, consequently, produced new meanings to study.

Pythagoras portrays this transformation well when he says that "this is where the magic started to happen". When referring to the moment when the preparation for the Olympiads began, the student points out that it was magical, in short, it was not something usual, known, it was something special. This sense reveals that there was a change in Pythagoras' psychological state. Before venturing to prepare for the competition, he considered that this activity would not bring positive results, because he did not feel able to live this experience, even so he accepted the challenge of studying and preparing to participate in the competition.

His involvement with other students and his approach to a new way of studying mathematics led him to produce a new sense of studying this subject. If studying before meant fulfilling an obligation, this activity ceased to be felt as an obligation and started to mean joy, happiness and pride. He now felt that "he had something special to study". It was no longer a matter of studying to pass the year, to fulfill the tasks and to meet the teachers' demands. These particularities, although they existed, no longer predominantly mediated his study activity, they gave way to the desire to maintain the satisfaction that studying in mathematics provided him. His decision to take the Mathematics course in Higher Education reflects that his involvement with this area of knowledge went beyond the basic schooling process, it is a choice for life, so much so that he says "Today I am a student of the course at Mathematics at UFPI, and I feel very happy for that". These meanings reveal that the experience provided by the mathematics Olympiad led Pythagoras to transform the reasons for studying mathematics, their motivations are not subject to the external world, but in the desire to deepen a knowledge that completes him, which cheers him up. He is a cause of himself and, being a cause of himself, he comes to have adequate ideas about studying mathematics. (Espinosa, 2008). 
Espinosa (2008) uses the definitions of action and passion to show that individuals, in relation to reality, can be the cause of themselves, or just, submit to the variation of external causes. When the human being acts submitted to external causes of which he is unaware, or to particularities of which he is a partial cause, he actually suffers, because he is commanded by external forces. When the cause of his activity is the result of his needs and not of imposed needs, when his action exists not only to meet the particularities of everyday life, but to achieve something that is useful to him, and even when his action is regulated by affects that he knows, Espinosa (2008) considers that the subject is active in the world. The capacity or lack of capacity of human beings to act, according to this author, is related to needs. For the philosopher, being free does not mean not having needs, but awareness of them, awareness of affections, "because there is no other power of the mind other than that of thinking and forming appropriate ideas" (Espinosa, 2008, p. 373) .

With Isaac, this process was even more significant. The student recognizes that he did not like to attend classes, did not see himself as a hard-working student and did the least possible, just to guarantee the average and pass. These meanings reinforce the thesis that Isaac did not produce personal sense to be at school, to study or to strive as a student. This sense was produced when he started to participate in the Olympiads. This fact, according to him, changed his life. We observed that Isaac had his relationship with the school context transformed with his participation in the Olympiads due to the fact of winning medals, because that meant the valorization of his potential. These were situations and relationships that affected him with joy, increasing the power to act. The mathematics Olympiads favored the recognition of himself as capable, the awareness of a potential, "And from then on everything in my life would change [...] I had discovered something that I was good at" (Isaac, excerpts from the memorial). If we take into account what Vigotski (2010) points out about the experience being related to the process of becoming aware, we understand that the fact that Isaac perceives himself as capable, as someone capable of learning something new, reveals, once again, that participation in the mathematics Olympiads was an experience for Isaac, because the student transformed his relationship with studies because he became aware of his potential. This meaning about him changed his relationship with school and studies. The formation of a new concept about oneself mediated a new affective situation. This is a strong indication that Isaac experienced a social development situation, that is, an experience.

Raquel also brings meanings that reveal how much participation in this educational practice mediated her transformation as a student. In her account she makes it clear that it was not a smooth process; on the contrary, she narrates that she went through difficulties and that the teacher's mediation was very important to not let her give up, "I really liked math! But even so, I couldn't get through to the second phase of these Olympiads [...] I was a very young, I didn't understand the value that these Olympiads would have in my life, however, Prof. Torricelli never gave up on encouraging me "(Raquel, excerpts from the memorial). 
The fact that the teacher did not give up on encouraging her was a particularity that affected her in a decisive way and would produce states of satisfaction in her school life that would lead her to change in relation to the results she was pursuing so much, "I managed to pass that same year for the 2nd phase of the Brazilian Public Schools Mathematics Olympiad [...] I got two Honorable Mentions, and a Bronze Medal. It was in these last three years of study in my city that the influences of my teachers stood out". (Raquel, excerpts from the memorial).

The mention that Raquel makes to the teachers proves the importance of the teacher in the development of the students' potential. Vigotski (2010), referring to this issue, summarizes that the teacher, as an experienced pair and holder of the final and ideal form of development that he seeks to achieve for his student, by organizing quality educational practices at school allows the student's interaction with this final formal development. The organization of these educational practices in school spaces ensures that the school consolidates itself as "a means of development that it plays in relation to the superior specific properties of man and forms of action, the role of a source of development" (Vigotski, 2010, p. 697).

Raquel's account shows that the awards obtained through the Olympiads were experienced with joy. This experience, source of joyful affections, produces self-esteem, self-confidence, pleasure and satisfaction. If before she resented being unable to pass the stage, at this point in her life she not only passed the stage, but also stood out and felt encouraged to study other school subjects: "I loved studying chemistry, biology, mathematics ... and with the results in the Olympiad, I started to get more and more excited"(Raquel, excerpts from the memorial). These affections were responsible for the increase in Raquel's intellectual power. With her increased power, the student is able to stand out not only in mathematics, but also in other subjects that represent the different areas of human knowledge. Espinosa (2008) warns that only the rational power of knowledge allows to gradually transform the lives of individuals and lead them to enjoy active affections; affects that lead to active learning.

Considering what happened to Pitágoras, Isaac and Raquel, it is worth mentioning that these students experienced a situation of experience. Our statement is supported by the Vigotskian idea that the experience synthesizes the relationship between the individual and the world. The way in which the individual becomes aware and conceives the events of the world in which he lives and the way in which he relates affectionately to certain events, in short, the experience "is the prism that determines the role and the influence of the environment in the development of the character of the child, his psychological development and so on" (Vigotski, 2010, p. 686).

The experience, therefore, represents, on the one hand, the environment, that which is represented, that which is located outside the person. In the case referred to here, the environment is represented by the school, by study activities, by the relationship with mathematics and by the Olympiads, by the mediation of teachers. On the other hand, it is represented how the person experiences the environment, how he feels the experience, the affections constituted in the relationship with the environment. In the case of students, it refers to the way they are subjectifying this relationship, what they are 
feeling, how they are giving meaning to involvement in the Olympiads. It means, therefore, that the experience synthesizes the dialectic of the particularities that are, at the same time, of the environment and the person. In this sense, we agree with Brandão (2012) about the experience being the category of Socio-Historical Psychology that attests to Vigotski's monist conception, because through experience, man and reality are dialectically constituted.

The development of this educational practice produced changes in the lives of not only the students who were directly involved, but also encouraged changes in behavior in the school group. Teachers and students began to assume a commitment beyond the classroom, taking responsibility for the training of each other, as a kind of collective affectation, "As time went by, a study group was formed [...] and this group [...] now it was up to them to prepare the youngest students". Thus, a culture of valuing teaching and learning was created, where cooperation is practiced: "In high school [...] Professor Torricelli's project was now followed by other subjects, which began to follow the same methodology and prepare students now for other Olympiads". What happens at this school, that is, the fact that other teachers and students feel encouraged to participate and get involved with the mathematics Olympiad, or even, the fact that other teachers try to organize similar practices in their subjects happens because, according to Espinosa (2008, p. 325) "Whoever lives under the guidance of reason wishes, also for another, the good that he wants for himself."

In this explanation lies the sense that, in cooperation, there is an increase in individual powers, because in cooperation individuals share common interests, their natures combine with each other, so their power to act tends to be stimulated and reinforced. Therefore, this confirms what Espinosa (2008) affirms that nothing can better match the nature of a being than other individuals of the same species, who share the same interests and discover common needs. We are convinced that teachers and students at that school discovered common needs and, for that reason, feel encouraged to share the same experiences, since "All other teachers also started to engage in the Olympiads and gave extra classes". (Raquel, excerpts from the memorial).

For all that has been pointed out here, we consider that the mathematics Olympiad was a fundamental educational practice in the process of transforming the meaning constituted by students about the study activity. The analyzes showed that, when organizing this meeting, the teacher produced the conditions under which students, affected by the experience produced in the involvement with this practice, underwent transformations that activated the desire to learn, not only to meet immediate needs, but, above all, to change their lives, confirming the words of Silva and Gomes (2017) that desire is what enhances our development.

Modé Magalhães and Martins (2020) in recent research clarify that any transformation that the student experiences at school is indicative of the formation of a new concept, a new way of understanding reality. However, concept formation, which is a superior psychological function, does not take place in the absence of processes of meaning, that is, of production of meanings. Thus, the mathematics Olympiads constituted experiences 
that led students to the formation of new higher psychological functions and the transformation of the senses about studying.

Studying has become a personal commitment assumed by everyone, as everyone has been affected in such a way that this activity is not just a stage in their lives, but a way of asserting themselves as humans, as bodies that expand with each new encounter, that transform and overflow potential (Silva and Gomes, 2017).

Thus, we confirm the thesis announced in the introduction of this article: the teacher who affects his students positively (with joy) is affected by satisfaction, means that he himself is positively affected (with joy). To maintain the state of satisfaction that increases the power to act, he continues to develop educational practices that collaborate with the students'success, because the students' success is their success, it is the expansion of their joy. In turn, when students are positively affected, they create a meaningful relationship that potentiates the desire to continue learning and developing.

This thesis leads us to many conclusions, the most important of which is the idea that the teacher ethically committed to education develops his educational practice with effort, educates to make the bodies of his students other bodies, transformed, capable of much more things and greater actions than you can imagine. Educating affected by the desire to affect the student's desire, this is the subjective condition that needs to be produced by teachers who seek to carry out successful educational practice.

\section{CONCLUSION}

This research originated from an interest in answering the following question: how does the affect-intellect relationship impact the development of the consciousness of teachers and students to the point of favoring an increase in the desire to continue learning and developing?

As an answer to this problem, we present in this article results of bibliographic and empirical research with the objective of analyzing the relationship between affection and intellect in the process of development of teachers and students who experience successful educational practice. The results can be summarized in the following considerations:

The school as a socio-cultural space is a meeting place between teachers and students who, together, share the process of transmission, appropriation and production of knowledge. As a meeting space, they are organized based on the socio-affective relationships that mediate the production of desires, leading to the understanding that the act of teaching and learning never happens without affection. Therefore, it is the affections that guide the action of teachers and students in educational relationships, since there is no education without desire and neither desire without education.

The increase or decrease in the power that teachers and students have to develop more in school and in life depends on the type of affection that causes the active or passive desire. We understand, therefore, that in education, affectation is the process by which educational practices are transformed into affective experiences capable of increasing or decreasing the power of human development, as Vigotski and Espinosa assert. 
Based on the ideas of these theorists, we defend the thesis that the teacher is able to carry out a successful educational practice when he is affected and positively affects his students. In turn, when students are positively affected, they create a meaningful relationship that enhances the desire to continue learning and developing. Currently, it is a permanent challenge to instigate educational practices that lead to the appreciation of the active desire of teachers and students. This objective depends on the objective and subjective conditions that will determine the type of affectation that will constitute the encounter between them.

The theoretical-practical considerations addressed in this article show the understanding that the affectivity-intellect relationship is a fundamental mediation in the process of constituting teachers and students who experience educational processes.

We also emphasize that the affections of joy enhance the active desire of teachers and students, placing them in an activity situation, which means greater awareness in the activity, or the appearance of new higher psychological functions that improve the quality of social relations and raise chances that educational practices will promote learning and development.

However, we cannot ignore that conscience is the product of man's material activity and that the level of consciousness in the activity depends on the personal relationship that is produced in life, in practical actions, by the objective and subjective conditions that the human being has to act in the world.

Therefore, the analysis of educational practices that maximize human development requires examining the objective and subjective conditions that both teachers have to develop their main activity, which is teaching, as well as the affective conditions that students have to learn and develop.

\section{REFERENCES}

Alencar Marques, E. S., \& Carvalho, M. V. C. (2018). Prática educativa, vivência e afetos na constituição de alunos com histórias de sucesso na escola. EDUCAÇÃO E FILOSOFIA, 32(65).https://doi.org/10.14393/REVEDFIL.issn.01026801.v32n65a2018-12

Carvalho, L.; Braga, E. de M.; Andrade, A. V.; Assis, L. P. (2019). Emoção, afeto e racionalidade: em direção a uma ontologia do agente cognitivo. In. Alves, M. A. (Org). Cognição, emoção e ação. Marília: Oficina Universitária; São Paulo: Cultura Acadêmica, pp. 177-200.

Chaui, M. (2005). Espinosa: uma filosofia da liberdade. São Paulo: Moderna.

Chaui, M. (2011). Desejo, paixão e ação na Ética de Espinosa. São Paulo: Companhia das letras.

Costa - Pinto, A. B. (2012). Potência de agir e educação ambiental: aproximações a partir de uma análise da experiência do coletivo educador ambiental de Campinas (COEDUCA) SP/Brasil. 164 f. Thesis (Doctorate) - Programa de Pós-graduação em Ciência Ambiental. Universidade de São Paulo: Departamento de Filosofia da Faculdade de Letras, Universidade de Lisboa. 
Costa - Pinto, A. B.; Rodrigues, L. (2013). Reflexões sobre a educação em Espinosa: a experiência do encontro como segundo nascimento. Filosofia e Educação. Campinas, vol. 5, n. 01. Availableat: http://www.fae.unicamp.br/revista/index.php/rfe/article/view/4390/3836. Access: jun 12, 2013.

Duarte, N. ( 2004) Formação do individuo, consciência e alienação: o ser humano na psicologia de A. N. Leontiev. Cad. CEDES [ Online]. Vol. 24, n. 62.Available at: www.scielo.br/scielo.php?script=sci_arttext\&pid=s0101.

Espinosa, B. de. (2008). Ética. Belo Horizonte: Autêntica.

Espinosa, B. de.( 2007). Tratado da reforma do entendimento. São Paulo: Escala.

Fragoso, E. A. da R. ; Itokazu, E. M. (2012). Introdução. In.: Espinosa, B. de. Breve tratado de Deus, do homem e do seu bem-estar. Belo Horizonte: Autêntica Editora.

Gazzotti, D., \& Souza, M. P. R. de. (2019). A emoção e o ensino-aprendizagem em uma perspectiva histórico-cultural: uma pesquisa na educação infantil bilíngue. Obutchénie: Revista De Didática E Psicologia Pedagógica,3(2), 1-23. https://doi.org/10.14393/OBv3n2.a2019-51562

Merçon, J. (2012). O desejo como essência da educação. Filosofia e Educação, v. 5, n. 1 , apr/set. Available https://www.fe.unicamp.br/revistas/ged/rfe/article/view/3630/3812.Access: oct 5, 2012.

Modé Magalhães, G. e Márcia Martins, L. (2020) “Onze teses sobre a relação entre psicologia educacional e pedagogia escolar”, Revista Educação em Questão, 58(55). https://doi: 10.21680/1981-1802.2020v58n55ID19150

Paes, P. C. D. (2020). Funções psicológicas superiores e o enraizamento da cultura na individualidade. Brazilian Journal of Development, 6(7), 43489-43500, Curitiba, v. 6, n. $7, \quad$ p. 43489-43500 jul. 2020. Disponível em https://www.brazilianjournals.com/index.php/BRJD/article/view/12694

Saviani, D. (1991). Educação e questões da atualidade. São Paulo: Cortez.

Silva, M. F., \& Gomes, C. (2017). Afeto na filosofia de espinosa: aportes para potencialização dos corpos na escola. Revista Sul-Americana de Filosofia e Educação, Brasilia, 1(27), 119-135. https://doi.org/10.26512/resafe.v0i27.4883

Toassa, G. (2019). Muito além dos padrões: as emoções como objeto interdisciplinar. In. Alves, M. A. (Org). Cognição, emoção e ação. Marília: Oficina Universitária; São Paulo: Cultura Acadêmica, pp. 177-200.

Vigotski, L. S. ( 2004). Teoria e método em psicologia. São Paulo: Martins Fontes.

Vigotski. L. S. (2009). A construção do pensamento e da linguagem.São Paulo: Martins Fontes.

Vigotski. L. S. Psicologia pedagógica: edição comentada.Porto Alegre: Artmed.

Vigotski. L. S. (1996). La crisis de los siete años. In: VIGOTSKI, L. S. Obras escogidas. Tomo IV. Madrid: Visor. 